\title{
A NEW REVERSE PHASE HPLC METHOD WITH FLUORESCENT DETECTION FOR THE DETERMINATION OF SALBUTAMOL SULFATE IN HUMAN PLASMA
}

\author{
Ghulam Murtaza, Mahmood Ahmad*, Muhammad Asadullah Madni and Muhammad Waheed \\ Asghar \\ Department of Pharmaceutics, Faculty of Pharmacy and Alternative Medicines, The Islamia \\ University of Bahawalpur, Bahawalpur 63100, Pakistan
}

(Received March 4, 2008; revised July 31, 2008)

\begin{abstract}
A sensitive reverse phase-high performance liquid chromatography (RP-HPLC) method with fluorescent detector (FLD) was developed and optimized for salbutamol sulfate (SS) determination in human plasma. In this regard, mobile phase specifications, extraction procedures and excitation and emission wavelengths were optimized. The HPLC system consisted of a Lichrosorb RP-C18 analytical column $(4.6 \times 200$ $\mathrm{mm}, 5 \mu \mathrm{m}$ ) with FLD operated at excitation $228 \mathrm{~nm}$ and emission $310 \mathrm{~nm}$. Mobile phase $\left\{\mathrm{CH}_{3} \mathrm{OH} /\left(\mathrm{NH}_{4}\right) \mathrm{H}_{2} \mathrm{PO}_{4}\right.$ $(67 \mathrm{mM})(\mathrm{pH} 3.0) /$ triethylamine (TEA), 50/50/0.02 (v/v/v \%) \} was run at a flow rate of $0.7 \mathrm{~mL} / \mathrm{min}$. To clean up the samples, a liquid-liquid extraction (LLE) procedure was selected and optimized. SS and tramadol hydrochloride $(\mathrm{TH})$ eluted at $4.1 \mathrm{~min}$ and $5.2 \mathrm{~min}$, respectively. Adequate extraction efficiency was achieved by DEHP (75.88-85.52\%). The standard curve was linear for the range tested $(0.5-80 \mathrm{ng} / \mathrm{mL})$ and the coefficient of determination was 0.9989 . A detection limit of $0.17 \mathrm{ng} / \mathrm{mL}$ was achieved. The intra- and inter-day precision was less than $4 \%$. The present assay combines adequate accuracy and precision with sensitivity for SS determination in human plasma and can be applied to study pharmacokinetics of SS sustained release tablets after oral administration in human.
\end{abstract}

KEY WORDS: Salbutamol sulfate, RP-HPLC method, Fluorescent detection, Ion-pair extraction, Human plasma

\section{INTRODUCTION}

Salbutamol, 1-(4-hydroxy-3-hydroxy-methyl phenyl)-2-(tert-butylamino) ethanol $\left(\mathrm{C}_{13} \mathrm{H}_{21} \mathrm{NO}_{3}\right)$, is a short acting $\beta_{2}$-adrenergic receptor agonist used for the relief of bronchospasm in conditions such as asthma and chronic obstructive pulmonary diseases. This compound contains a phenylethanolamine nucleus having a $\beta$-hydroxylamino group on the side chain, as shown in Figure 1 (A). Salbutamol sulfate (SS) is usually given by the inhaled route for direct effect on bronchial smooth muscle [1, 2]. It can also be given orally or intravenously. Despite the fact that SS is well absorbed, its systemic bioavailability is only $50 \%$ due to extensive presystemic metabolism in the gastrointestinal tract and liver $[3,4]$.

This work is a part of the sustained release microencapsulated formulation development of SS and its pharmacokinetic evaluation in human. We developed a RP-HPLC method for the quantitation of SS from human plasma for the comparison of developed formulation with that of the marketed formulation. According to literature, several analytical methods have been developed for SS determination in the dosage forms and biofluids [5-10].

In this context, we were interested to develop sensitive and specific HPLC method with FLD for the quantitative assay of SS in human plasma after LLE and the application of the method to a preliminary pharmacokinetic study in human. In order to optimize the separation, different chromatographic conditions were also studied and are described in this paper.

Chemicals and reagents

\section{EXPERIMENTAL}

Salbutamol sulfate (SS), tramadol hydrochloride (TH) and diclofenac sodium (DS) were gifted by Unexo Laboratories (Pakistan), Ali Gohar Pharmaceuticals (AGP, Pakistan) and Sami

*Corresponding author. E-mail: ma786_786@yahoo.com 
Pharmaceuticals (Pakistan), respectively. Ventolin $8 \mathrm{mg}$ SR tablets were provided by Glaxosmithkline (GSK, Pakistan). All other reagents (analytical grade or chromatography grade) were purchased from commercial sources and were used as received without further purification. Potassium dihydrogen phosphate $\left(\mathrm{KH}_{2} \mathrm{PO}_{4}\right)$, ammonium dihydrogen phosphate $\left(\left(\mathrm{NH}_{4}\right) \mathrm{H}_{2} \mathrm{PO}_{4}\right)$, acetonitrile $\left(\mathrm{CH}_{3} \mathrm{CN}\right)$, methanol $\left(\mathrm{CH}_{3} \mathrm{OH}\right)$, phosphoric acid $\left(\mathrm{H}_{3} \mathrm{PO}_{4}\right)$, ammonium acetate $\left(\mathrm{CH}_{3} \mathrm{COONH}_{4}\right)$, acetic acid $\left(\mathrm{CH}_{3} \mathrm{COOH}\right)$, hydrochloric acid $(\mathrm{HCl})$, sodium dihydrogen phosphate $\left(\mathrm{NaH}_{2} \mathrm{PO}_{4}\right)$, di(2-ethylhexyl) phosphate (DEHP), perchloric acid $\left(\mathrm{HClO}_{4}\right)$ were supplied by Merck (Germany) and tri-ethylamine (TEA) by Fluka (Switzerland). Chloroform and sodium dodecyl sulfate (SDS) were supplied by BDH (UK). Bamethan sulfate (BS) was purchased from Sigma (USA). Human blood was obtained from healthy human volunteers in Bahawal Victoria Hospital (BVH), Bahawalpur, Pakistan. Water was distilled with water distillation apparatus (IRMECO Gmbh-IM100, Geesthacht, Germany).

\section{Instrumentation}

High Performance Liquid Chromatographic System (Agilent Technologies, 1200 Series, USA) consisted of a water solvent delivery system, an iso pump (G1310A) and a Rheodyne attached with $100 \mu \mathrm{L}$ loop. The above system was controlled by the ChemStation software equipped with a fluorescent detector (FLD, G1321A). A Hettich centrifuge EBA 20, Zentrifugen D-78532 (Tuttlingen, Germany) was utilized to centrifuge plasma samples. For $\mathrm{pH}$ measurement, a $\mathrm{pH}$ meter (Inolab, Germany) calibrated with standard buffers was employed.

\section{Chromatographic conditions}

A Lichrosorb RP-C18 stainless steel analytical column $(4.6 \times 200 \mathrm{~mm}, 5 \mu \mathrm{m})$ (Agilent, USA) was used. HPLC system was operated at room temperature. Mobile phase of following composition $\mathrm{CH}_{3} \mathrm{OH}:\left(\mathrm{NH}_{4}\right) \mathrm{H}_{2} \mathrm{PO}_{4}(67 \mathrm{mM})\left(\mathrm{pH} 3.0\right.$ adjusted with $\left.\mathrm{H}_{3} \mathrm{PO}_{4}\right)$ : TEA, 50:50:0.02 $(\mathrm{v} / \mathrm{v} / \mathrm{v} \%)$ was prepared, filtered through Cellulose Acetate Filter $(0.45 \mu \mathrm{m}$ pore size, Sartorius, AG37070 Goettingen, Germany) and degassed by sonicator (T490DH, Elma, Germany) at $70 \mathrm{~Hz}$ before use. Mobile phase was delivered at a rate of $0.7 \mathrm{~mL} / \mathrm{min}$. Injection volume was $100 \mu \mathrm{L}$. FLD was operated at excitation wavelength $228 \mathrm{~nm}$ and emission wavelength $310 \mathrm{~nm}$.

\section{Preparation of samples}

$100 \mathrm{mg}$ of SS was dissolved in $100 \mathrm{~mL}$ of double distilled water to produce its stock solution (1 $\mathrm{mg} / \mathrm{mL}$ ). Then it was diluted to 5, 10, 50, 100, 200, 400 and $800 \mathrm{ng} / \mathrm{mL}$ (SS working standard solutions) by adding mobile phase. Similarly, $2 \mu \mathrm{g} / \mathrm{mL}$ working standard solution of internal standard (TH) was prepared from its stock solution $(1 \mathrm{mg} / \mathrm{mL})$. Spiked plasma standards $(0.5$, $1.0,5,10,20,40$ and $80 \mathrm{ng} / \mathrm{mL}$ ) were prepared by adding $100 \mu \mathrm{L}$ of SS working standard solutions to $860 \mu \mathrm{L}$ of drug free human plasma received from a healthy young volunteer. $40 \mu \mathrm{L}$ ( $4 \mathrm{ng} / 40 \mu \mathrm{L}$ ) of $\mathrm{TH}$ working solution was also added to each concentration. One blank plasma sample (plasma without drug and internal standard) was analyzed with calibration standards. Another set of spiked plasma standards (1.0, 40 and $80 \mathrm{ng} / \mathrm{mL})$ was prepared without internal standard and stored at $-20^{\circ} \mathrm{C}$ to investigate SS stability over a period of 16 days.

\section{Optimization studies}

Process variables. (1) Compositions of solvent mixtures as mobile phase, as given in Table 1, (2) concentration of $\left(\mathrm{NH}_{4}\right) \mathrm{H}_{2} \mathrm{PO}_{4}(47 ; 57 ; 67 \mathrm{mM})$, (3) volume percent of $\mathrm{CH}_{3} \mathrm{CN}(30 ; 50 ; 70)$, (4) $\mathrm{pH}$ of the mobile phase $(3.0 ; 4.0 ; 5.0),(5)$ excitation and emission wavelengths of FLD, (6) flow rate of mobile phase $(0.5 ; 0.7 ; 0.9)$, (7) choice of internal standard (BS, TH, DS), and (8) 
choice of protein extracting agent $\left(\mathrm{CH}_{3} \mathrm{OH}, \mathrm{CH}_{3} \mathrm{CN}\right.$, DEHP and $\left.\mathrm{HClO}_{4}\right)$ and its amount. Each factor was examined at different levels which were chosen as such and/or smaller and/or higher than the nominal level as determined in the preliminary optimization.

\section{Sample clean up procedures}

Protein extraction by DEHP. $5.5 \mathrm{~mL}$ of $0.1 \mathrm{M}$ DEHP in chloroform was added to $1.0 \mathrm{~mL}$ plasma sample in $10 \mathrm{~mL}$ glass tube. The resultant was agitated gently in the upright position on a vortex mixer for $10 \mathrm{~min}$ followed by centrifugation at $2000 \mathrm{rpm}$ for $10 \mathrm{~min}$. The chloroform layer was shifted to another $10 \mathrm{~mL}$ glass tube already containing $1 \mathrm{~mL}$ of $0.5 \mathrm{M} \mathrm{HCl}$. The resultant was agitated gently as before for $10 \mathrm{~min}$, and then centrifuged at $2000 \mathrm{rpm}$ for $10 \mathrm{~min}$. A $100 \mu \mathrm{L}$ aliquot of the acidic layer was injected into the sample loop of HPLC manually. Then unextracted standards were also prepared in $0.5 \mathrm{M} \mathrm{HCl}$ to determine extraction efficiency. The clear supernatant layer was then injected to the HPLC system.

Protein extraction by $\mathrm{CH}_{3} \mathrm{OH} / \mathrm{CH}_{3} \mathrm{CN} / \mathrm{HClO}_{4}$. To $1.0 \mathrm{~mL}$ plasma sample in a glass tube, $1 \mathrm{~mL}$ of $\mathrm{CH}_{3} \mathrm{OH}$ or $\mathrm{CH}_{3} \mathrm{CN}$ or $30 \mu \mathrm{L}$ of $\mathrm{HClO}_{4}$ was added. The resultant was vortexed gently for 10 min and centrifuged at $2000 \mathrm{rpm}$ for $10 \mathrm{~min}$. The protein precipitates down and an aliquot of $100 \mu \mathrm{L}$ of clear layer were injected into HPLC manually. Then their unextracted samples were prepared to determine extraction efficiency. The clear supernatant layer was then injected to the HPLC system.

\section{Validation of the method}

The newly developed chromatographic method was validated in the light of FDA guidelines [11], i.e. specificity, accuracy, precision, linearity (calibration curve), range, detection limit (LOD), quantitation limit (LOQ), robustness, ruggedness, extraction efficiency and stability.

\section{Application to study pharmacokinetics}

The method narrated above was applied to quantify the plasma concentration of SS in a single dose pharmacokinetic study conducted on two healthy human volunteers (25 and 27 years old weighting about 65 and $75 \mathrm{~kg}$, respectively). Before administration, the human volunteers were fasted for $16 \mathrm{~h}$ from food but not water. A commercially available ventolin $8 \mathrm{mg}$ SR was administered orally to each human volunteer. Blood samples were drawn at $0,0.25,0.5,0.75,1$, $1.5,2,2.5,3,4,6,8,10,12,14 \mathrm{~h}$ by means of a catheter. After centrifugation at $4500 \mathrm{rpm}$ for $10 \mathrm{~min}$, the supernatant plasma layer was stored at $-20{ }^{\circ} \mathrm{C}$ until assayed. The protocol of study was approved by the committee for research of the Islamia University of Bahawalpur, Bahawalpur, Pakistan.

\section{RESULTS AND DISCUSSION}

\section{Optimization studies}

SS is a basic compound with $\mathrm{pK}_{\mathrm{a}}=9.3$ and 10.3 [12]. Problems with SS peak shape are fairly common. But there are many simple steps that can dramatically improve the peak shape of problematic SS. These steps are discussed below. Although earlier HPLC methods were accurate and precise for SS determination but the present study is an attempt to develop a HPLC method with better sensitivity. 
Mobile phase. In the search of an appropriate mobile phase, initially the use of buffer was avoided (mobile phase 1-5 in the Table 1). However, to achieve the better sensitivity and short analysis time, four different phosphate buffers were employed into study (mobile phase 6-13 in the Table 1). The retention time was found to be maximum in case of $\mathrm{CH}_{3} \mathrm{COONH}_{4}$ buffer, followed by $\mathrm{NaH}_{2} \mathrm{PO}_{4}, \mathrm{KH}_{2} \mathrm{PO}_{4}$ and $\left(\mathrm{NH}_{4}\right) \mathrm{H}_{2} \mathrm{PO}_{4}$, respectively, while all other HPLC conditions were kept constant. However, following increasing trend is observed on the basis of their peak area as they all produced sharp well resolved peaks; $\mathrm{NaH}_{2} \mathrm{PO}_{4}<\mathrm{CH}_{3} \mathrm{COONH}_{4}<\mathrm{KH}_{2} \mathrm{PO}_{4}<$ $\left(\mathrm{NH}_{4}\right) \mathrm{H}_{2} \mathrm{PO}_{4}$. In this attempt, $\left(\mathrm{NH}_{4}\right) \mathrm{H}_{2} \mathrm{PO}_{4}$ buffer was selected for further studies as it showed good sensitivity than other three buffers. Instead of $\mathrm{CH}_{3} \mathrm{CN}$ as organic solvent, $\mathrm{CH}_{3} \mathrm{OH}$ proved itself a good partner of $\left(\mathrm{NH}_{4}\right) \mathrm{H}_{2} \mathrm{PO}_{4}$ buffer because it slightly improved the sensitivity of method.

Table 1. Mobile phases and their percentage compositions by volume employed in the development of a HPLC method for the detection of salbutamol sulfate in human plasma.

\begin{tabular}{|l|l|l|}
\hline S. No. & Mobile phase & Composition (v/v \%) \\
\hline 1 & $\mathrm{CH}_{3} \mathrm{CN}: \mathrm{H}_{2} \mathrm{O}$ & $8: 92$ and 10:90 \\
\hline 2 & $\mathrm{CH}_{3} \mathrm{CN}: \mathrm{H}_{2} \mathrm{O}: \mathrm{H}_{3} \mathrm{PO}_{4}$ & $8: 91.85: 0.15$ \\
\hline 3 & $\mathrm{CH}_{3} \mathrm{CN}: \mathrm{H}_{2} \mathrm{O}: \mathrm{H}_{3} \mathrm{PO}_{4}$ & $8: 91.8: 0.2$ \\
\hline 4 & $\mathrm{CH}_{3} \mathrm{CN}: \mathrm{H}_{2} \mathrm{O}: \mathrm{CH}_{3} \mathrm{OH}$ & $10: 70: 20$ \\
\hline 5 & $\mathrm{CH}_{3} \mathrm{OH}: \mathrm{CH}_{3} \mathrm{COOH}: \mathrm{TEA}\left(\mathrm{pH} 3.0\right.$ adjusted with $\left.\mathrm{H}_{3} \mathrm{PO}_{4}\right)$ & $100: 0.001: 0.001$ \\
\hline 6 & $\mathrm{CH}_{3} \mathrm{CN}: \mathrm{NaH}_{2} \mathrm{PO}_{4}(40 \mathrm{mM})\left(\mathrm{pH} 3.0\right.$ adjusted with $\left.\mathrm{H}_{3} \mathrm{PO}_{4}\right)$ & $8: 92$ \\
\hline 7 & $\mathrm{CH}_{3} \mathrm{CN}: \mathrm{CH}_{3} \mathrm{COONH}_{4}(0.1 \mathrm{M}$ and $1 \mathrm{M})\left(\mathrm{pH} 3.0\right.$ adjusted with $\left.\mathrm{CH}_{3} \mathrm{COOH}\right)$ & $8: 92$ \\
\hline 8 & $\mathrm{CH}_{3} \mathrm{CN}: \mathrm{KH}_{2} \mathrm{PO}_{4}(40 \mathrm{mM})\left(\mathrm{pH} 3.0\right.$ adjusted with $\left.\mathrm{H}_{3} \mathrm{PO}_{4}\right)$ & $8: 92$ \\
\hline 9 & $\mathrm{CH}_{3} \mathrm{OH}:\left(\mathrm{NH}_{4}\right) \mathrm{H}_{2} \mathrm{PO}_{4}(67 \mathrm{mM})\left(\mathrm{pH} 3.0\right.$ adjusted with $\left.\mathrm{H}_{3} \mathrm{PO}_{4}\right)$ & $50: 50$ and 30:70 and $70: 30$ \\
\hline 10 & $\mathrm{CH}_{3} \mathrm{OH}:\left(\mathrm{NH}_{4}\right) \mathrm{H}_{2} \mathrm{PO}_{4}(67 \mathrm{mM})\left(\mathrm{pH} 3.0\right.$ adjusted with $\left.\mathrm{H}_{3} \mathrm{PO}_{4}\right): \mathrm{TEA}$ & $50: 50: 0.02$ \\
\hline 11 & $\mathrm{CH}_{3} \mathrm{CN}:\left(\mathrm{NH}_{4}\right) \mathrm{H}_{2} \mathrm{PO}_{4}(67 \mathrm{mM})\left(\mathrm{pH} 3.0\right.$ adjusted with $\left.\mathrm{H}_{3} \mathrm{PO}_{4}\right): \mathrm{TEA}$ & $50: 50: 0.02$ \\
\hline 12 & $\mathrm{CH}_{3} \mathrm{OH}:\left(\mathrm{NH}_{4}\right) \mathrm{H}_{2} \mathrm{PO}_{4}(67 \mathrm{mM})\left(\mathrm{pH} 3.0\right.$ adjusted with $\left.\mathrm{H}_{3} \mathrm{PO}_{4}\right): \mathrm{TEA}: \mathrm{SDS}$ & $50: 50: 0.02: 0.5$ \\
\hline 13 & $\mathrm{CH}_{3} \mathrm{CN}:\left(\mathrm{NH}_{4}\right) \mathrm{H}_{2} \mathrm{PO}_{4}(67 \mathrm{mM})\left(\mathrm{pH} 3.0\right.$ adjusted with $\left.\mathrm{H}_{3} \mathrm{PO}_{4}\right): \mathrm{CH}_{3} \mathrm{OH}$ & $4.4: 92.2: 3.4$ \\
\hline
\end{tabular}

Secondly, $\left(\mathrm{NH}_{4}\right) \mathrm{H}_{2} \mathrm{PO}_{4}$ concentration used were 47, 57 and $67 \mathrm{mM}$. Increase in buffer concentration reduced peak tailing for SS and TH and an improvement in peak symmetry was achieved by increasing $\left(\mathrm{NH}_{4}\right) \mathrm{H}_{2} \mathrm{PO}_{4}$ concentration from $47 \mathrm{mM}$ to $67 \mathrm{mM}$. An increase in buffer strength might suppress interactions between SS and stationary phase/silanol groups. Thus buffer concentration was $67 \mathrm{mM}$ at which the resolution and sensitivity of SS and TH was optimum.

Due to high $\mathrm{pK}_{\mathrm{a}}$ value and low solubility of SS in a medium with high $\mathrm{pH}$, SS has a positive charge on it over the normal useable range of silica based HPLC columns. To prevent ionexchange interactions between the positively charged SS and negatively charged silanol groups, the mobile phase $\mathrm{pH}$ should be low enough to protonate all silanol groups on the silica surface. By this measure, the peak tailing which results from ion-exchange interactions was easily avoided. Therefore, the effect of $\mathrm{pH}$ was investigated within the range of 3.0-5.0. No significant change in retention time but slight decrease in sensitivity was observed with an increase in $\mathrm{pH}$. Ultimately, the optimum detection of SS was achieved at $\mathrm{pH} 3.0$ at which resolution factor $\left(\mathrm{R}_{\mathrm{s}}\right)$ were greater than 2.0 for almost every peak.

SS and triethylamine (TEA), both contain amino group, as shown in Figure 1 (B), thus TEA (an ion-pairing organic modifier) was added to $\mathrm{CH}_{3} \mathrm{OH}-\left(\mathrm{NH}_{4}\right) \mathrm{H}_{2} \mathrm{PO}_{4}(67 \mathrm{mM})$ as a final step to improve SS peak symmetry. TEA acts as a competing base and minimizes SS-silanol interactions because it pairs with silanol groups of the stationary phase. Thus quick elution of SS effectively sharpens peaks resulting in improved peak resolution. A $0.5 \%$ SDS (displacing agent) was also used as a micellar phase to enhance the solubility of proteins and to minimize 
binding of SS to plasma proteins. Although it enhanced sensitivity to some extent but variable retention time and slightly broad peaks rejected its use in the finally selected mobile phase.<smiles>CC(C)(C)NC[C@@H](O)c1ccc(O)c(CO)c1</smiles>

(A)<smiles>CCN(CC)CC</smiles>

(B)<smiles>COc1cccc(C2(O)CCCCC2CN(C)C)c1</smiles>

(C)

Figure 1. Structural formulas of salbutamol (A), triethylamine (B) and tramadol (C).

Choice of internal standard. TH (structural formula of tramadol is given in Figure 1 (C)), was chosen as the most appropriate one in the present analysis because the peaks of TH and SS had $\mathrm{R}_{\mathrm{s}}>2.0$ and were symmetrical (asymmetry factor of TH and SS, determined at $10 \%$ of total of peak height, were 1.07 and 1.10 , respectively). TH eluted without interfering the peaks of plasma and SS as the retention time of SS and TH was $4.1 \mathrm{~min}$ and $5.2 \mathrm{~min}$, respectively. As a result, the run time was set at $15 \mathrm{~min} / \mathrm{sample}$. TH also met all the other typical requirements of a compound to be used an internal standard (e.g. stability, proper solubility).

In the second phase of optimization, different excitation and emission wavelengths were used without varying other parameters. Optimal response was obtained with excitation at 228 $\mathrm{nm}$ and emission at $310 \mathrm{~nm}$. Following the above mentioned conditions, a flow rate of 0.7 $\mathrm{mL} / \mathrm{min}$ showed good resolution of peaks.

As a final phase of optimization strategy, plasma samples were treated with different extracting chemicals, i.e. $\mathrm{CH}_{3} \mathrm{OH}, \mathrm{CH}_{3} \mathrm{CN}$, DEHP and $\mathrm{HClO}_{4} \cdot \mathrm{CH}_{3} \mathrm{OH}, \mathrm{CH}_{3} \mathrm{CN}$ and $\mathrm{HClO}_{4}$ produced diffused peaks of TH and SS. Whereas DEHP showed good resolution $\left(\mathrm{R}_{\mathrm{s}}>2.0\right)$ of every peak and its nearest ones. DEHP showed better extraction efficiency $(75.88-85.52 \%$ of SS and $82.28 \%$ of TH). $5.5 \mathrm{~mL}$ of $0.1 \mathrm{M}$ DEHP produced highest extraction efficiency along with $1 \mathrm{~mL}$ of $0.5 \mathrm{M} \mathrm{HCl}$ for $1.0 \mathrm{~mL}$ plasma $[5,8]$.

The best conditions for the separation of SS from TH and plasma components are at mobile phase compositions: $\mathrm{CH}_{3} \mathrm{OH}:\left(\mathrm{NH}_{4}\right) \mathrm{H}_{2} \mathrm{PO}_{4}(67 \mathrm{mM})\left(\mathrm{pH} 3.0\right.$ adjusted with $\left.\mathrm{H}_{3} \mathrm{PO}_{4}\right)$ :TEA, 50:50:0.02 (v/v/v \%) when it is run at a rate of $0.7 \mathrm{~mL} / \mathrm{min}$ with excitation at $228 \mathrm{~nm}$ and emission at $310 \mathrm{~nm}$.

Validation of method. After the above optimization, a linear calibration curve for SS was obtained in the concentrations range of $0.5-80 \mathrm{ng} / \mathrm{mL}(\mathrm{n}=7)$. Regression analysis was done on the basis of peak-area of SS (y) in human plasma versus its concentration (x) and a good linearity (0.9989) was observed. The results are presented in the Table 2 and Figure 2. Preparing and analyzing standards of three SS concentrations (low, intermediate and high quality control samples; $0.5,10,80 \mathrm{ng} / \mathrm{mL}$ ) three times, intra- and inter-day relative standard deviation (RSD) values were calculated. Intra- and inter-day RSD for SS in plasma were less then $4 \%$ while Intra- and inter-day accuracy were more than $95 \%$ as shown in Table 3. These values showed that the proposed method has high repeatability and precision for SS analysis. LOD and LOQ were estimated by signal to noise ratio of $3: 1$ and 10:1, respectively, by following expressions (i) and (ii):

$\mathrm{LOD}=3.3 \mathrm{~s} / \mathrm{S}$

$\mathrm{LOQ}=10 \mathrm{~s} / \mathrm{S}$ 
Where "s" is the standard deviation of blank readings or standard deviation of the regression line and " $\mathrm{S}$ " is the slope of calibration curve. Based on the above equation, the calculated LOD value for SS in plasma was $0.17 \mathrm{ng} / \mathrm{mL}$ while the LOQ one was $0.5 \mathrm{ng} / \mathrm{mL}$ as given in Table 2 . Thus the present method is also one of the most sensitive ones for SS determination in human plasma $[5,6,10]$. Stability of SS spiked in human plasma was evaluated at the same three concentration levels $(0.5,10,80 \mathrm{ng} / \mathrm{mL})$ with eleven equally prepared samples at each level. The conditions examined were freeze-thaw cycles, storage in the dark at $-20{ }^{\circ} \mathrm{C}$ for the period of 16 days. No significant variation $(p>0.5)$ was observed in the peak area even after 16 days than that of the first day.

Table 2. Regression analysis of calibration line.

\begin{tabular}{|l|l|l|}
\hline Serial No. & Parameters & Values of biofluid samples \\
\hline 1 & Number of samples & 7 \\
\hline 2 & Concentration range $(\mathrm{ng} / \mathrm{mL})$ & $0.5-80$ \\
\hline 3 & Regression equation & $\mathrm{y}=\mathrm{ax}+\mathrm{b}$ \\
\hline 4 & Slope $(\mathrm{a})$ & 162.1 \\
\hline 5 & Intercept $(\mathrm{b})$ & 67.717 \\
\hline 6 & Coefficient of determination $\left(\mathrm{r}^{2}\right)$ & 0.9989 \\
\hline 7 & Coefficient of correlation $(\mathrm{r})$ & 0.9994 \\
\hline 8 & LOQ $(\mathrm{ng} / \mathrm{mL})$ & 0.5 \\
\hline 9 & LOD $(\mathrm{ng} / \mathrm{mL})$ & 0.17 \\
\hline 10 & Extraction efficiency ${ }^{*}(\%)$ & $75.88-85.52$ \\
\hline
\end{tabular}

*Extraction efficiency $=$ (peak area of biofluid samples/peak area of mobile phase samples $) \times 100$.

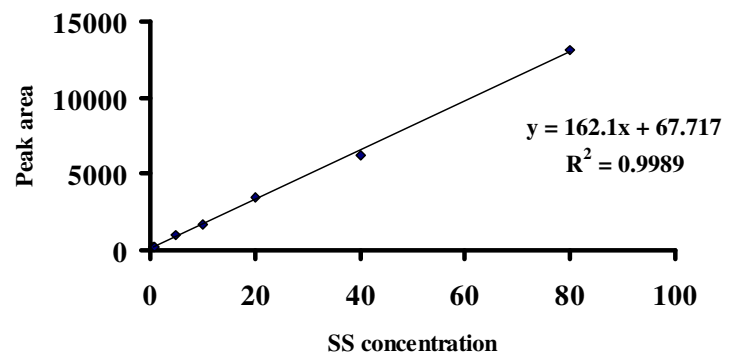

Figure 2. Calibration curve (area of SS peak in spiked plasma versus concentration) of salbutamol sulfate in human plasma.

Pharmacokinetic studies

The resultant pharmacokinetic (representative mean plasma concentrations versus time) profile of SS in the human plasma is shown in Figure 3. The corresponding pharmacokinetic parameters from noncompartmental analysis of the data have been summarized in Table 4. The $\mathrm{T}_{\max }, \mathrm{C}_{\max }$ and $T_{1 / 2}$ of SS in the present study were similar, although the intake doses were different from those reported in literature [7, 8, 13, 14]. A typical HPLC chromatogram was obtained and presented in Figure 4 which showed SS along with TH in human plasma, after 75 min of drug administration. Good resolution for every peak was assured by $\mathrm{R}_{\mathrm{s}}>1.5$. 
HPLC method for the determination of Salbutamol sulfate in human plasma

Table 3. Summary of intra-day and inter-day precision and accuracy data $(n=3)$ for proposed method in human plasma.

\begin{tabular}{|c|c|c|c|c|c|c|c|}
\hline \multirow{2}{*}{$\begin{array}{l}\text { Serial } \\
\text { No. }\end{array}$} & \multirow{2}{*}{$\begin{array}{l}\text { Added } \\
\text { concentration } \\
(\mathrm{ng} / \mathrm{mL})\end{array}$} & \multicolumn{3}{|l|}{ Intra-day } & \multicolumn{3}{|l|}{ Inter-day } \\
\hline & & $\begin{array}{l}\text { Found } \\
\text { Concentration } \\
(\mathrm{ng} / \mathrm{mL})\end{array}$ & $\begin{array}{l}\text { Precision } \\
\operatorname{RSD}^{\mathrm{b}}(\%)\end{array}$ & $\begin{array}{l}\text { Accuracy } \\
\text { (bias \%) }\end{array}$ & $\begin{array}{l}\text { Found } \\
\text { Concentration } \\
(\mathrm{ng} / \mathrm{mL})\end{array}$ & $\begin{array}{l}\text { Precision } \\
\operatorname{RSD}^{\mathrm{b}}(\%)\end{array}$ & $\begin{array}{l}\text { Accuracy } \\
\text { (bias \%) }\end{array}$ \\
\hline 1 & 0.5 & $0.5 \pm 0.02$ & 3.35 & 0.56 & $0.49 \pm 0.02$ & 3.86 & -1.20 \\
\hline 2 & 1.0 & $9.86 \pm 0.05$ & 0.52 & -1.42 & $9.89 \pm 0.09$ & 0.89 & -1.10 \\
\hline 3 & 80 & $80.98 \pm 0.43$ & 0.53 & 1.22 & $81.06 \pm 0.36$ & 0.44 & 1.31 \\
\hline
\end{tabular}

${ }^{\mathrm{a}}$ Found concentration: mean \pm standard deviation. ${ }^{\mathrm{b}}$ Precision RSD $(\%)$ : (standard deviation $\left./ \mathrm{mean}\right) \times 100$.

${ }^{\mathrm{c}}$ Accuracy (bias \%): ((found concentration - added concentration)/added concentration) $\times 100$.

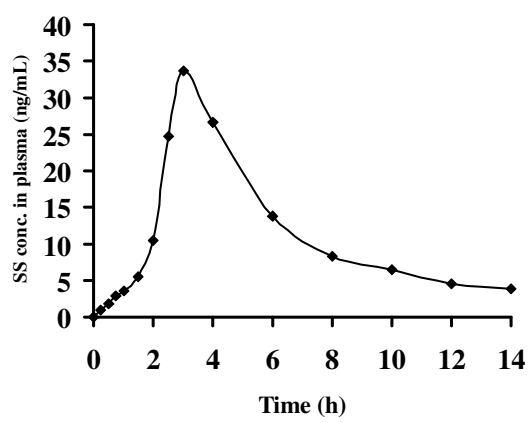

Figure 3. Pharmacokinetic profile $(\mathrm{n}=2)$ of salbutamol sulfate in human plasma after single oral administration of a commercially available tablet ( $8 \mathrm{mg}$ Ventolin SR).

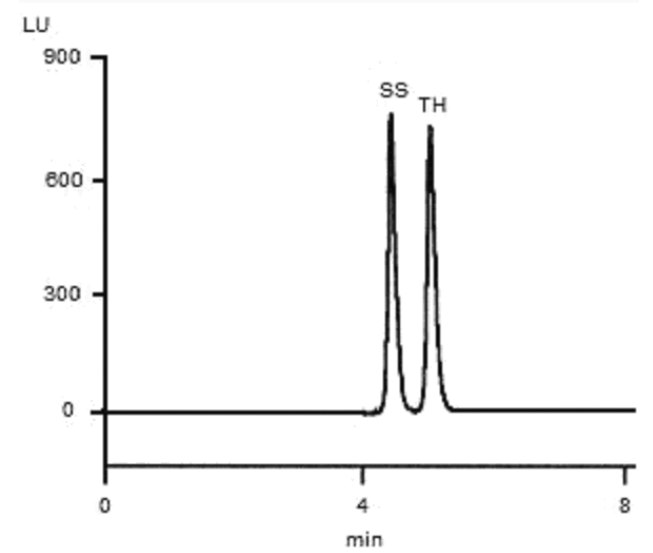

Figure 4. A typical chromatograph obtained under the optimized experimental conditions. 
Table 4. Pharmacokinetic parameters $(n=2)$ of salbutamol sulfate in human plasma after single oral administration of a commercially available tablet (8 mg Ventolin SR).

\begin{tabular}{|c|c|c|}
\hline Serial No. & Pharmacokinetic parameters & Observed values \\
\hline 1 & Maximum plasma concentration $\left(\mathrm{C}_{\max }, \mathrm{ng} / \mathrm{mL}\right)$ & 33.63 \\
\hline 2 & Time required for maximum plasma concentration $\left(T_{\max }, h\right)$ & 3.0 \\
\hline 3 & Elimination rate constant $\left(\mathrm{K}_{\mathrm{el}}, \mathrm{h}^{-1}\right)$ & 0.14 \\
\hline 4 & Area under curve $_{\text {(total) }}\left(\mathrm{AUC}_{\text {(total) }}(\mathrm{ng} \mathrm{h} / \mathrm{mL})\right.$ & 184.1 \\
\hline 5 & Area under momentum curve ${ }_{\text {(total }}\left(\mathrm{AUMC}_{(\text {total) }}\left(\mathrm{ng} \mathrm{h}^{2} / \mathrm{mL}\right)\right.$ & 1476 \\
\hline 6 & Volume of distribution $\left(\mathrm{V}_{\mathrm{d}}, \mathrm{mL}\right)$ & 0.32 \\
\hline 7 & Plasma half life $\left(\mathrm{T}_{1 / 2}, \mathrm{~h}\right)$ & 5.12 \\
\hline 8 & Mean residence time (MRT, h) & 8.02 \\
\hline 9 & Total clearance rate $(\mathrm{TCR}, \mathrm{l} / \mathrm{h})$ & 0.0434 \\
\hline
\end{tabular}

\section{CONCLUSIONS}

In the present study, a new sensitive and specific RP-HPLC method has been developed, optimized and validated for SS estimation in human plasma using FLD and isocratic elution. Optimization elaborated that the mobile phase composition and excitation and emission wavelengths of FLD are as crucial parameters as flow rate for reproducible and quantitative determination of the SS. The method was found to be linear over an analytical range of 0.5-80 $\mathrm{ng} / \mathrm{mL}$ with $\mathrm{LOD}=0.17 \mathrm{ng} / \mathrm{mL}$ and $\mathrm{LOQ}=0.5 \mathrm{ng} / \mathrm{mL}$, respectively. An excellent accuracy $(>$ $95 \%)$ and precision $(<4 \%)$ was achieved. The method can be used successfully in routine drug monitoring and pharmacokinetic studies.

\section{AKNOWLEDGEMENTS}

The authors are very grateful for the financial support given by the Higher Education Commission (HEC) of Pakistan. They also thank to the management of Unexo Laboratories, Ali Gohar Pharmaceuticals and Sami Pharmaceuticals for their kind donation of analytical purity grade salbutamol sulfate, tramadol hydrochloride and diclofenac sodium.

\section{REFERENCES}

1. Ouyang, J.; Duan, J.L.; Baeyens, W.R.G.; Delanghe, J.R. Talanta 2005, 65, 1.

2. Dolley, C. Therapeutic Drug, Vol. 2. Churchill Livingstone: London; 1991; p 51.

3. Martineau, L.; Horan, M.A.; Rothwell, N.J.; Little, R.A. Clin. Sci. 1992, 83, 615.

4. Caruso, J.F.; Signorile, J.F.; Perry, A.C.; LeBlank, B.; Williams, R.; Clark, M. Med. Sci. Sports Exerc. 1995, 27, 1471.

5. Hutchings, M.K.; Paul, J.D.; Morgan, D.J. J. Chromatogr. 1983, 277, 423.

6. Sagar, K.A.; Hua, C.; Kelly, M.T.; Smyth, M.R. Electroanalysis 1992, 4, 481.

7. Saleh, M.L.; Koh, Y.M.; Tan, S.C.; Aishah, A.L. Analyst 2000, 125, 1569.

8. Sutariya, V.B.; Mashru, R.C.; Sankalia, M.G.; Sankalia, J.M. Ars. Pharm. 2006, 47, 185.

9. Forsdahl, G.; Gmeiner, G. J. Sep. Sci. 2004, 27, 110.

10. Qin, Y.; Zou, Y.; Liang, M.; Yu, Q.; Huang, Y.; Li, T.; Xu, X. Sichuan. Da. Xue. Xue. Bao. Yi. Xue. Ban. 2003, 34, 576.

11. FDA Guidance for the Industry: Analytical Method Validation, US Food and Drug Administration, Center for Drug Evaluation and Research (CDER), Rockville MD; 2000.

12. Sutariya, V.B.; Mashru, R.C.; Sankalia, M.G.; Sankaliya, J.M. Ars. Pharm. 2005, 46, 337.

13. Ong, H.; Adam, A.; Perreault, S.; Marleau, S.; Bellemare, M.; Souich, P. D.; Beaulieu, N. J. Chromatogr. 1989, 497, 213.

14. Yuan, Y.S.; Li, K.; Zhao, F.L. Therap. Drug Monit. 1998, 20, 624.

Bull. Chem. Soc. Ethiop. 2009, 23(1) 